\title{
4
}

\section{IMAGINING GLOBAL ADIVASI-NESS}

\section{Celebrating World Adivasi Day in Chhotaudepur ${ }^{1}$}

\author{
Gregory D. Alles
}

In order to ensure that adivasis throughout the world receive human rights, and on behalf of their way of life, knowledge traditions, and human development, the United Nations (UNO) established a committee. This committee's first meeting took place on the 9th of August 1982. Ten years later, in 1993, "UNO" planned an "Earth Summit" in Rio de Janeiro, Brazil. In this summit as many as 400 adivasi leaders from 68 countries worldwide took part. Before the entire assembly these leaders made a strong appeal for global awareness of the need to protect adivasis and nature. In connection with that, in $1993 \mathrm{UNO}$, on the occasion of the first session of the eleventh meeting of the committee, proclaimed that 9th August be celebrated as World Adivasi Day. And after that, from the year 1994 the 9th of August has been celebrated the world over as Adivasi Day. ${ }^{2}$

The preceding excerpt is translated from a flyer that was distributed in the town of Chhotaudepur in eastern Gujarat and surrounding villages in August 2017. I received copies of the flyer from friends via WhatsApp. The U.N. committee that the flyer mentions but never names is the Working Group on Indigenous Populations. It has now been replaced by the Expert Mechanism on the Rights of Indigenous Peoples and, with greater visibility but a different charge, the Permanent Forum on Indigenous Issues. Adivasis is a Gujarati word whose etymological meaning is 'first inhabitants'; in much of India it designates what are legally known as Scheduled Tribes (ST). In the flyer it is used where English speakers at the U.N. would use the word 'indigenous'. The Earth Summit in Rio de Janeiro, officially known as the United Nations Conference on Environment and Development (UNCED), actually took place in June 1992, not 1993. ${ }^{3}$ The celebration referred to is officially known (in English) as the International Day of the World's Indigenous Peoples. Partly for convenience, but also because it more closely corresponds to the conceptions of the people I am talking about, I will 
call it 'World Adivasi Day', a literal translation of the Gujarati Viśva Ādivāsī Divas (sometimes Viśva Ádivāsī Dìn). On a recommendation of the Working Group, this day was proclaimed by the U.N. General Assembly, not the Working Group, on 23rd December, 1994, and first celebrated on 9th August, 1995, not 1994. ${ }^{4}$ This dating makes the 2017 celebration the 23rd World Adivasi Day, as the title of the flyer (not given earlier) rightly states.

After the passage translated earlier, the text of the flyer changes direction:

What distinguishes us [i.e., adivasis] is a life and heritage ordered according to nature. "Adivasi" is not just a word; it clearly defines our history, life, and rights. Schedules 5 and 6 of the Indian Constitution and the PESA Act ${ }^{5}$ made under them are constitutional provisions for our rights as adivasis. It is the responsibility of the entire country, and especially our responsibility, to protect and ensure the implementation of these provisions for the sake of the care and development of adivasis and nature. So come, on this World Adivasi Day let us set aside our religious (dhärmik) ${ }^{6}$ and other private beliefs, our diverse political opinions, and differences of any other kind and together with the whole world let us, too, full of pride and with great ceremony, demonstrate the importance of our constitutional rights and their implementation of the development of our community, and let us make a grand celebration of adivasi dignity. It is especially requested that everyone come to this programme in our [traditional] dress and that everyone bring along all family members, including children. By means of a rally through the city, accompanied by our instruments and dancing, and by means of a public gathering we will make our celebration grand and memorable. ${ }^{7}$

Given this paragraph's emphasis on rights, it is odd - and telling - that the text makes no mention of the U.N. Declaration on the Rights of Indigenous Peoples (UNDRIP). The U.N. had officially designated the 2017 celebration of the International Day of the World's Indigenous Peoples as an occasion to celebrate the 10th anniversary of UNDRIP's adoption.

It is, of course, impossible to do justice to a celebration with words. As Nicola Frost observed in commenting on Goethe's 'Roman Carnival':

Because experiencing carnival is fundamentally a process of individual perception, a generalised account will always be found wanting . . precisely because of the noise and the bustle and general sensory excess, individual participants are unable to gain an overview of the whole event.

(Frost 2016: 573)

But part of what fascinates me about the celebration of World Adivasi Day in Chhotaudepur is the manner in which it conjoins elements from a number of scales, from the hyperlocal to the global. ${ }^{8}$ As the title of our project, Indigenous Religion(s): Local Grounds, Global Networks, indicates, these conjunctures are 
in many ways typical of indigeneity today. To be sure, the translations from, to be overly blunt, the local to the global - 'upscale' - and from the global to the local - 'downscale' - are not flawless. Translation never is (Venuti 2012, 2013). They do, however, say something distinctive about what it means to be indigenous - or better, adivasi - in this particular corner of India. To put the point much too bluntly: adivasi-ness is characterised by vigorous interactions locally but imagined interactions globally.

\section{Celebrating World Adivasi Day in Gujarat}

Chhotaudepur is the name of a district, sub-district (taluka), and town in eastern Gujarat, India. In the last Census (2011), the town had a population of a little more than 25,750 people. The majority of the town-dwellers are not adivasi. The vast majority of the district's inhabitants, however, live in rural villages, and they are overwhelmingly adivasi (roughly 95\%). People from several 'tribes' live in Chhotaudepur sub-district, including Nayakas, Dhanaks, Tadvis, and Bhils, but the largest community by far are Rathvas. Rathvas are not just numerically but also culturally, politically, and - among adivasis, at least - economically dominant. For example, since the early 1970s, with only one exception, MPs and MLAs from the constituencies surrounding Chhotaudepur have been Rathvas. ${ }^{9}$ More to the point here, the organisers of the World Adivasi Day celebrations in Chhotaudepur have almost all been Rathvas. ${ }^{10}$

I have not been able to determine when, where, why, how, or by whom World Adivasi Day was first celebrated in Gujarat. I have heard that adivasis decided to start celebrating it when India became a signatory to UNDRIP in 2007 but refused to acknowledge the existence of any indigenous people within its borders. I have heard this, but I have not been able to confirm it. In any case, it is a relatively safe assumption that there were several channels by which people in the Chhotaudepur area learned about the day.

I first became aware of World Adivasi Day from Adilok, a Gujarati magazine devoted to tribal culture, which carried an article about it in 2008 , its first year of publication. Every year since then, the September-October issue has contained reports about celebrations of World Adivasi Day by adivasis throughout Gujarat, although never in Chhotaudepur. But Adilok is certainly not the only line along which awareness of this day could have been transmitted to adivasis in Chhotaudepur. For example, Ashok Chaudhari, an adivasi activist from south Gujarat closely associated with the Adivasi Ekta Parishad, ${ }^{11}$ attended the Earth Summit in Rio de Janeiro in 1992. From 2001 to 2010 he was associated with the Adivasi Academy in Tejgadh, 10 kilometres from Chhotaudepur, for a time as director. Prof. Arjun Rathva (M.C. Rathva Arts College, Pavi Jetpur), a major planner of the Chhotaudepur World Adivasi Day celebrations, was also associated with the Adivasi Academy for several years, and he suspects that he first learned about World Adivasi Day from Chaudhuri in the early 2000s (Interview, Chhotaudepur, 11 August 2018). 
In any case, a year or two after Adilok began publication, in other words, in 2009 or 2010, a small group of people - perhaps 500 - began to celebrate World Adivasi Day in the Chhotaudepur area (Personal communication from Madhu Rathva, 7 May 2018). A video on Facebook purports to show the 2012 celebration, ${ }^{12}$ but I remained unaware of these celebrations until 2015, when I received photos from a friend. ${ }^{13}$ In that year the celebration consisted of performances typical for the area: men playing drums, men performing group dances, men brandishing bows and arrows, and a small ritual - all in a large courtyard. In the photos that I received women and children figure only as spectators, but this may just reflect the interests of the photographer. Unfortunately, because I was not much interested in the event at the time, I failed to ask follow-up questions.

In 2016 Chhotaudepur hosted at least two observances of World Adivasi Day. The one that I have been tracking grew larger. Among other things, it added a short rally through the streets of the town: people carrying formal signs identifying the rally as a celebration of World Adivasi Day, at least one group of motorbikes, and marchers. It also featured a more formal venue, with a backdrop consisting of large Pithora paintings on canvas (see more on Pithora paintings later in this chapter). In India as elsewhere, however, indigenous celebrations are ripe for exploitation by politicians and businesspeople (cf. Phipps 2016: 684; citing Henry 2008), and in 2016 the Congress Party organised its own celebration of World Adivasi Day in Chhotaudepur. Its celebration was attended by state and national officials: Bharatsinh Solanki, the state Congress President, and Amrinder Singh Raja Brar, an MLA from Punjab and Indian Youth Congress President. ${ }^{14}$

In 2017 political and social forces joined hands. There was only a single celebration, and it was a massive, all-day affair. According to one estimate, 5000 people participated; according to another, $10,000 .{ }^{15}$ In any case, given that only about 6400 adivasis live in Chhotaudepur town, the attendance was huge. ${ }^{16}$ It included a lengthy rally through the streets of the town, accompanied, in the words of the flyer (not translated earlier), "according to adivasi cultural tradition by dhol and nagara [two types of drums], a microphone [attached, naturally, to a loud-speaker system], and a D.J.". ${ }^{17}$ Following the rally was an assembly at a stage set up at Zanda Chowk in the centre of town. It consisted of a ritual observance; recognitions and awards for outstanding students and community workers; cultural performances; and speeches by various dignitaries, including the district collector at the time, V. J. Kharadi, himself an adivasi but a Dungra Bhil from Sabarkantha District some distance away. ${ }^{18}$

In 2018 I was finally able to observe the World Adivasi Day celebration in Chhotaudepur for myself. In form it followed the pattern established in 2017: a rally along the same route through town, followed by an assembly at Zanda Chowk consisting of similar events, minus the collector. Although the 2017 celebration had been a celebration for the inhabitants of Chhotaudepur taluka (sub-district), the 2018 celebration was intended to be a celebration for the entire district, but at the last minute - or rather, on the last weekend (4th-5th August) - politics once 
again intervened, this time from the direction of the BJP, the ruling party in the state. Despite what had been widely advertised, the Gujarat Minister of Tribal Welfare decided that the celebration for Chhotaudepur district would be held in Pavi Jetpur town instead of in Chhotaudepur. Although I was invited to the Pavi Jetpur celebration, I decided to stay in Chhotaudepur.

The Chhotaudepur rally was scheduled to depart at 9:00a.m., but when I arrived at the starting point at 9:35a.m. - I had been advised to come late - only police officers were present. The rally did not set off until just before noon, allegedly because heavy rains in the northeastern part of the taluka had made travel to Chhotaudepur town difficult. As a result, the assembly, originally scheduled for 12:30p.m., did not begin until about 2:45p.m. A heavy downpour greeted its beginning, and except for people sitting immediately in front of the stage, the audience stood on plastic chairs, tightly packed together and straining to see, protected by tarpaulins that were not completely effective. After about an hour, the crowd had become very thin - fortunately so, since around 4:00p.m. I myself was asked to give a short speech. The assembly came to an end around 5:30p.m. After posing for final pictures, the main participants danced together on stage, while everyone else, myself included, left.

There is little to say about the 2019 celebration. It was cancelled due to torrential rain. ${ }^{19}$

\section{The local and the global}

Crucial to the functioning of the Chhotaudepur celebration of World Adivasi Day is a conjunction of elements on a variety of scales, combined with a good deal of imaginative linking. The terms 'local' and 'global' begin to capture these elements and scales, but they only begin.

Consider the backdrop to the stage at the 2017 celebration. ${ }^{20}$ Prominently displayed in the centre was a sign that read in large, bold letters, "A hearty welcome to all of you on the occasion of World Adivasi Day". This text was superimposed upon a semi-transparent image of the U.N. symbol: the world, seen from the North Pole, surrounded by two olive branches. This symbol was in turn superimposed upon an image of a Pithora painting. U.N. symbol and Pithora painting, transnational and adivasi, global and local - what could be simpler?

But look again. Whom is the sign actually welcoming? According to the 2011 Census only $45.6 \%$ of Rathvas aged 30 to 34 - people 36 to 40 in 2017 - could read. By contrast, literacy among Rathvas who were teens at the time of the celebration was greater than $85 \%$. These figures mark an important difference: the sign addresses younger people more directly than older ones. But they also conceal an important difference. Literacy among men aged 30 to 34 at the time of the Census was almost $63 \%$, but among women of the same age it was only slightly more than $28 \%$ - a difference of more than $34 \%$. Furthermore, literacy statistics drop precipitously with age, so that among women 45 and older at the time of the Census - 51 and older at the time of the celebration - fewer than $10 \%$ could read. 
To those accustomed to more widespread literacy, these numbers may come as a shock, but the implication is clear: the sign addresses men more directly than women. But this statement, too, conceals an important difference. Since most Rathvas live in rural areas, the general statistics more or less reflect literacy among the rural population. They significantly understate literacy among urban Rathvas. Among Rathvas aged 30 to 34 at the time of the Census who lived in an urban setting, more than $82 \%$ of the men and almost $61 \%$ of the women could read. Unlike literacy among urban men, however, urban women's literacy drops rather rapidly with age, so that among urban Rathvas aged 50 to 54 at the time of the Census, 56 to 60 at the time of the celebration, almost $78 \%$ of the men could read, but slightly fewer than $28 \%$ of the women - a difference of $50 \%$.

In other words, although the text of the greeting addresses all people in attendance - and there is no reason to think that it is not sincere - the greeting itself actually speaks more directly to an audience that is young, urban, and male. These terms aptly describe both the organisers and the participants, too - except for residence, which is difficult to determine without conducting a survey. In 2017, one of the nine members of the planning committee was a woman, but apparently she did not attend the 2017 celebration, and she was not invited to participate in planning the 2018 event. The flyer announcing the 2018 celebration lists 22 members of the District Collection Committee, 24 political collaborators, and 23 members of the Local Planning Committee. Not a single one was a woman. The billboards announcing the event were similarly dominated by men's faces (Figure 4.1), ${ }^{21}$ and the participants in both the rally and the programme on stage were overwhelmingly male.

In both 2017 and 2018 girls appeared on stage as dancers in school groups, but they constituted a minority, and the women and girls recognised on stage

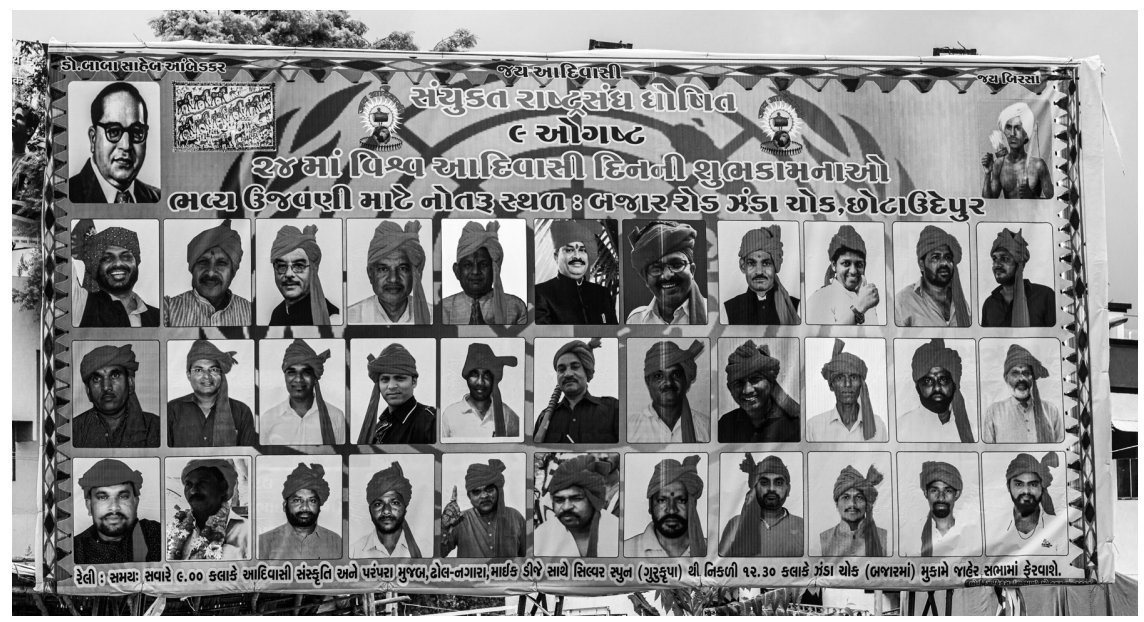

FIGURE 4.1 Billboard advertising 24th World Adivasi Day celebration, Chhotaudepur, 7 August 2018. 
were very few in number. When at the end of the programme in 2018 all of the speakers were summoned on stage for a final farewell, not a single woman was among them. ${ }^{22}$

Indeed, the celebration was thoroughly masculine - hypermasculine - in conception and implementation. ${ }^{23}$ The most common sign of adivasi identity was the $p \bar{a} g h d \bar{\imath}$, a traditional style of turban worn by men, but the second most common sign was weaponry. Men prominently displayed bows and arrows, scythes, clubs, and other weapons as they promenaded through the streets, danced in groups, and posed for photographs and selfies. ${ }^{24}$ The weapons signalled male adivasi strength, self-assertion, and tradition - even when (as I know occurred in at least one instance) they were bought especially for the occasion. Especially pervasive was the bow and arrow. On billboards it was associated with traditional adivasi heroes: Eklavya (an archer from the Mahabharata) and Birsa Munda (see more later in this chapter). One common image, pervasive on social media but also emblazoned on polo shirts at the event, shows the stylised silhouette of a bare, heavily musculatured male (sometimes just the upper body) shooting an arrow upwards. In a common phrase, recited in call and response fashion by all of the participants assembled on stage at the end of the programme, myself included, the bow and arrow even functioned as a metonym for the adivasi community: "Ek tīr, Ek kamān/Sabhī ādivāsī ek samān!" "One arrow, one bow/All adivasis are one and the same!"

\section{Seven scales}

Commenting on sociological thought in the decades bracketing the turn of the century, Peter Wagner notes:

The emergence and assertion of the individual as a being without predetermined strong connections to or within collectivities has moved to the centre of sociological interest. Together with the parallel debate on 'globalization', a sociological image of the contemporary world has emerged in which there are no social phenomena 'between' the singular human being, on the one hand, and structures of global extension, on the other.

(Wagner 2012: 66)

Such an atomised individual is most prominent, of course, among rationalchoice theorists, but one finds a similar dichotomy elsewhere, as when Anthony Giddens contrasts facework with abstract systems or writes of "the interlacing of distance and proximity, of the personal and the large-scale mechanisms of globalisation" (Giddens 1990: 88).

My contention here is that a simple dichotomy between the local and the global is too blunt to capture much of what goes on at the Chhotaudepur celebration of World Adivasi Day. I find it heuristically useful to identify activities and events on several different scales. ${ }^{25}$ Given boundaries imposed and maintained 
by both external and internal forces - legal definitions of adivasis as Scheduled Tribes, more or less strict endogamy within tribal communities - it may make some sense to talk of bounded communities in the Chhotaudepur area, but these scales also refer to different levels of "bundled connections" (Symons 2016: 710). I am not claiming that all societies reflect just these levels; at least for the moment it is best to think of them as reflecting a particular social imaginary as practised on the ground (Mukherji 2009: 130-133). The scales I identify are, in order of ascending time-space distanciation: ${ }^{26}$ personal, group, communal, local, state, regional-national, and transnational. Unless otherwise specified, specific descriptions that follow are of the 2018 celebration.

\section{Personal}

It seems self-evident that people bring to celebrations such as World Adivasi Day their own conceptions and aspirations, which intersect with other scales in various ways. Most conceptions and aspirations remain inaccessible to a researcher, but not all. In personal conversation Prof. Arjun Rathva insisted that the celebration was for the entire community and that no politicking, whether by the government or by any political party, was appropriate; Naranbhai Rathva, elected in March 2018 to the Rajya Sabha (India's upper house), echoed similar views. Prof. Shankarbhai Rathva, by contrast, a former BJP MLA, was committed to whatever celebration the state government declared official, even if that meant changing plans at the last minute. Vipul Rathva, who was introduced to me as the 'founder' of the Rath Sena, ${ }^{27}$ asked me to emphasise the need for education in my remarks from the stage, which he helped write. I did so, but I also stressed the significance of traditional adivasi culture, which the educated often reject.

Of course, different conceptions and aspirations have different degrees of impact that range along a spectrum from, as we sometimes say, private to public. Those that had the most public impact on the Chhotaudepur celebration of World Adivasi Day were probably those of the artist Lakshmanbhai Rathva, who apparently received free rein in all matters of graphic design. From flyers and billboards to the backdrop on the stage, his creations framed the visual experience of the celebration. Most effective, to my mind, were a series of banners, each depicting an adivasi hero, that hung from the lampposts in the centre of the streets through which the rally proceeded (Figure 4.2).

These banners were not, however, idiosyncratic creations, or even local ones. They depicted images that were and perhaps still are available for download on Google and Wikipedia and that circulated far beyond Chhotaudepur on social media platforms such as Facebook and WhatsApp.

\section{Group}

Some people - me, for example - participated in the Chhotaudepur celebration of World Adivasi Day more or less as individuals, but I suspect that the vast 


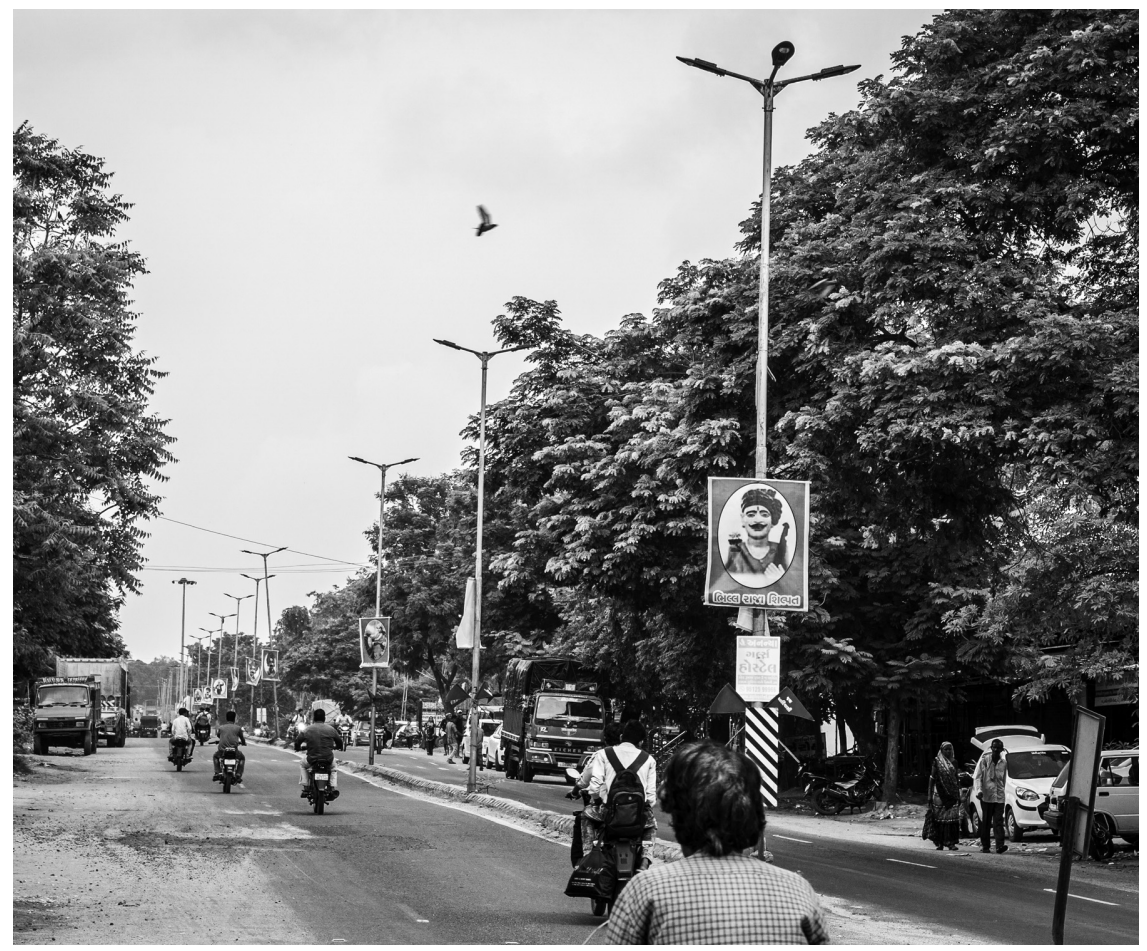

FIGURE 4.2 Banners along the rally route in preparation for World Adivasi Day celebration, Chhotaudepur, 8 August 2018.

majority did so as members of a group - or of several groups. Some groups had rather fluid boundaries. Friends or neighbours (often both) would run into each other during the rally, spend some time together, perhaps take a selfie or two, and then go their separate ways. I met several friends this way. In one case I met quite by accident a friend whom I had not seen for many years.

Other groups had more sharply defined boundaries. As often happens in the area, these boundaries were marked by clothing. The musicians who started off the rally wore dark green button-down shirts, white dhotis (a cloth wrapped around the waist), a blue triangular cloth around their hips, and red pāghdīs (turbans). Members of the Jay Adivasi Mahasangh Gujarat wore blue polo shirts with the name of the organisation emblazoned on the back. Another group wore pink polo shirts with a logo - widely available online - on the back and on the left-front pocket area: a full-body silhouette of a male archer in a circle with the caption "Jay Adivasi". Members of yet another group wore light green polo shirts with a similar logo - circle, archer, "Jay Adivasi" caption - along with the phrase (in Gujarati) "9th August International Day" scrolled around the top of both logos (Figure 4.3). 


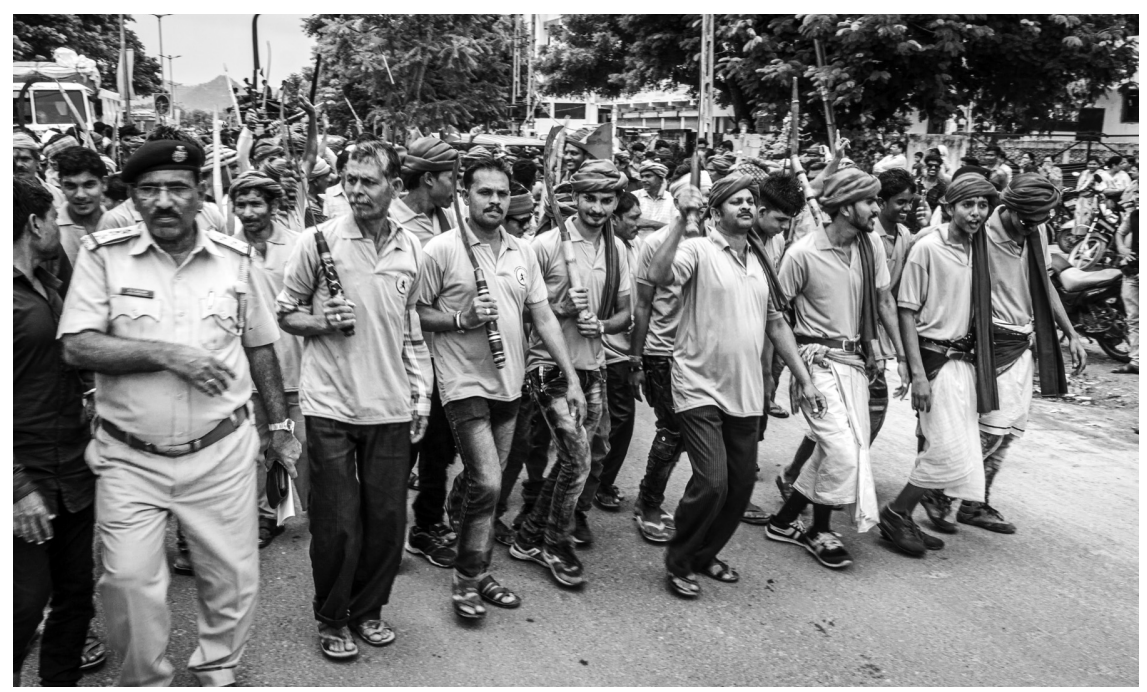

FIGURE 4.3 Marchers in the World Adivasi Day rally, Chhotaudepur, 9 August 2018.

School groups that performed on stage were similarly defined sartorially. One group of boys stood out for emphasising adivasi identity through a particularly 'primitive' look seen only in festivals. Their mostly bare bodies were covered with painted white and occasionally black decorations, they wore knee-length skirts of leafy strands over shorts, and they sported thick red headbands into which had been stuffed large, green leaves, standing upright.

Yet other groups fell somewhere along a spectrum between the diffuse and the well-bounded. Such groups include the politicians and other leaders who initially marched together at the front of the procession; a group of about 30 women who walked together further back; and persons, dispersed through the crowds, wearing paper badges with the U.N. symbol on a yellow field - the event organisers, I later learned. Not to be overlooked were the police in uniform who accompanied the rally. Some of them, both men and women, were themselves adivasi.

\section{Communal}

In India the term 'communal' bears a particular meaning. It refers to distinct 'communities' who live side by side in the same locality. A prime example is the phrase 'communal violence', which usually designates violence between communities defined by religion (or dharma): Hindu, Muslim, Sikh, Christian, and so on. Here, however, I am using the term 'communal' to refer to a social, not a religious community, namely, the community of adivasis, and specifically to 
the community of adivasis who can reasonably be expected to participate in the Chhotaudepur celebration of World Adivasi Day.

As we have already seen, this community is fractured in terms of literacy, age, sex, residency, and specific 'tribal' identity (Rathva, Nayaka, Dhanak, Tadvi, and Bhil). The organisers of the Chhotaudepur World Adivasi Day celebration have more or less ignored these divisions, which manifest themselves in the quintessential participant being a relatively young, literate Rathva man who has a close association with Chhotaudepur town. They have not, however, ignored two other divisive factors, as the promotional flyer makes clear. One of these factors is politics: varying political loyalties resulted in competing celebrations in both 2016 and 2018. The second divisive factor that the flyer mentions is religion, dharma. Within the adivasi community, religion is a powerful divisive force.

In other parts of India, such as the Northeast, indigenous peoples have converted to Christianity in large numbers, but in the Chhotaudepur area the vast majority of adivasis self-identify as Hindu. The major religious rift is not between adivasi Hindus, Muslims, Sikhs, Christians, and Jains. It is between traditionalists and assimilationists, known locally as jagats and bhagats, respectively. Jagats traditionalists - make animal sacrifices and offer libations of alcohol to gods, goddesses, and ancestors; they generally also eat meat and drink alcohol themselves. Bhagats, influenced by the values of caste Hindus, consider these practices to be uncivilised, and they themselves avoid meat and alcohol in everyday life at least they are supposed to - as well as in ritual. This rift can and does lead to contention within villages, for example during observances at village shrines, and within households, for example between husbands and wives.

The Chhotaudepur celebrations employ two strategies to overcome religious divisions, both of which may strike Europeans and North Americans as quintessentially modern. First, they dismiss religious differences as matters of private belief - amgat manyata ${ }^{28}$ At least, those who wrote the flyer do. It is difficult to say how widespread this conception is. Second, they transform various elements of jagat religious practice into tokens of communal identity by secularising, aestheticising, and 'heritagising' them.

For example, badva - religious leaders who traditionally heal and embody various deities when they become possessed - initiated the formal programme. They did so by, among other things, offering coconuts (in lieu of animal sacrifice) at a table in front of the stage that contained elements familiar from jagat rituals: glazed terracotta horses; a dhabu, that is, a terracotta residence for a deity; pots and oil lamps set up on mounds of paddy (unhusked rice), all marked with tipna (orange-red dots applied when reciting mantras) and tied round with red threads (Figure 4.4).

This opening ceremony was as much secularised culture as it was religion; requiring no assent to specifically jagat practices, it could be embraced by all. Even more telling was the widespread use of Pithora paintings on flyers, billboards, and backdrops to performances. Pithoras depict the marriage procession of Babo Pithoro, the most important Rathva god. Originally only a segment of the Rathva community known as Moti Nats used them; they had specialists 


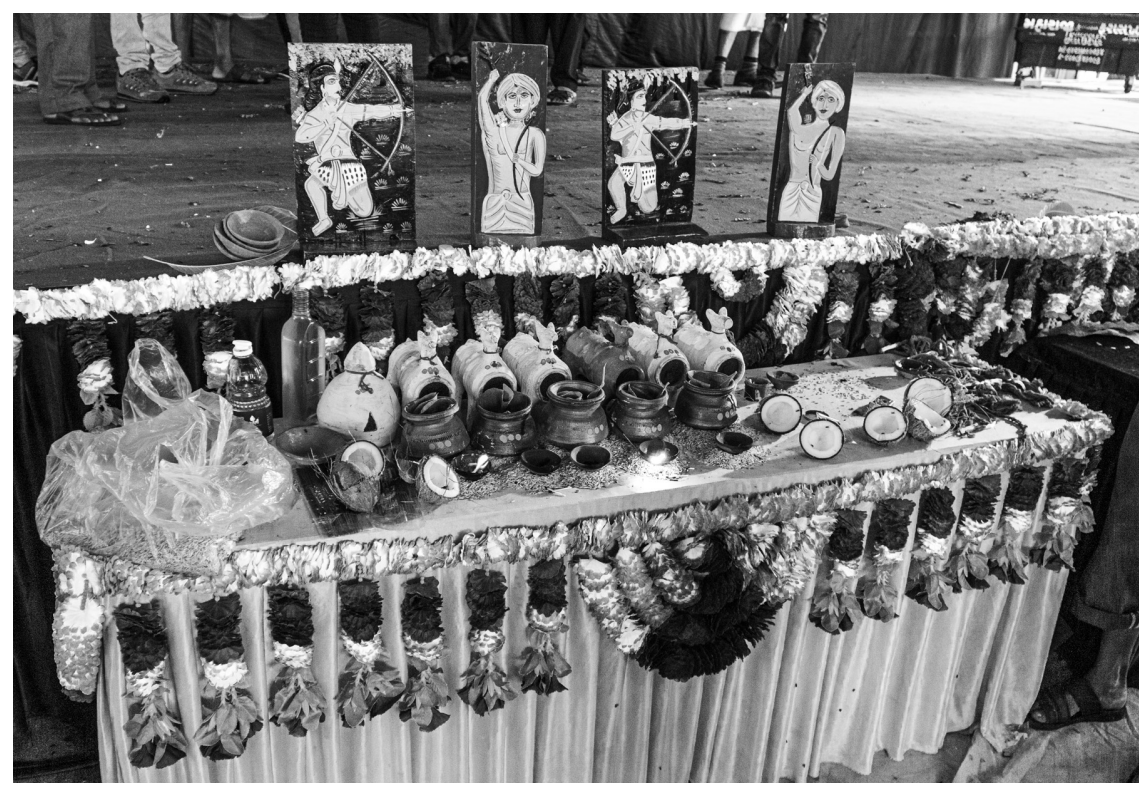

FIGURE 4.4 Table with ritual implements in front of the stage at the World Adivasi Day celebration, Chhotaudepur, 9 August 2018.

paint them on the walls of their houses in recognition of healing and in fulfillment of vows. Today, however, painted on canvas, Pithoras have become commodified in handicrafts markets. They have also become general markers of adivasi identity, found in such disparate places as the walls of the local Circuit House (a guest house for visiting government officials) and the local Catholic high school, in the latter case combined with depictions of Bible stories. The Rathsena - the 'Rathva army', founded 10th June, 2018 - has envisioned an even more formal recognition of Pithoras as cultural heritage. One of their stated goals is to acquire a 'GI tag' - a geographical indication tag - for the Pithora. The Pithora would then serve as a distinctive marker of Rathva identity, much as champagne characterises a region of France and Nürnberger sausages a city in Germany.

\section{Local}

The Chhotaudepur celebration of World Adivasi Day is conceived of as a local embodiment of a global event. Over time, however, the extension of 'local' has grown. In the early days, the celebration was centred on the area around Chhotaudepur town. By 2017 it had grown to include all of Chhotaudepur subdistrict. In 2018 the organisers decided to extend the celebration to the entire district. They asked other sub-districts to hold World Adivasi Day celebrations on Sunday, 5th August. The sub-district of Kavant did so; perhaps others did as 
well. Nevertheless, it proved difficult to make the celebration an all-inclusive district-wide event.

The organisers of the Chhotaudepur celebration attempted to define the local character of the event in several ways. One way was through performances by school groups from various parts of the locality served. In this respect the 2018 celebration was disappointing; only three school groups participated. Two other elements of the formal programme in 2018 also served to define the celebration as district-wide: the recognition of the accomplishments of various adivasis throughout the district and the speeches by persons with some claim to districtwide significance, most notably Mohansinh Rathva, a politician of long standing.

In other words, the 2018 Chhotaudepur celebration proved to be more locally encompassing in idea than in realisation. The erection of billboards throughout the district to advertise the event communicated the idea, and the flyer did so even more explicitly. While the 2017 flyer had identified the Chhotaudepur celebration as a sub-district one, the 2018 flyer explicitly invited people to participate in a 'district-level' celebration. It underscored this extension by publishing the names of the District Collection Committee. But even this list belied the event's district-wide character. Six members of the committee belonged to Chhotaudepur sub-district, six more to Pavi Jetpur sub-district (immediately to the west), and four to Kavant sub-district (immediately to the south). Only two members each belonged to Bodeli and Nasvadi sub-districts, and only one to Sankheda, all farther away.

As things turned out, it was not so much geography as politics - or geography exploited by politicians - that frustrated the aspiration to hold a district-wide celebration in Chhotaudepur. Both the 2017 and 2018 flyers stated in bold: "This programme is completely non-political". But as already noted, the weekend before the 2018 celebration the Gujarat State Minister for Tribal Welfare determined that the official district celebration should be held in Pavi Jetpur, allegedly because that town is more centrally located. The government also devoted 5 lakh rupees ( 500,000), a locally significant sum, to the Pavi Jetpur celebration. Buses brought school children from around the district; district, taluka, and village officials were present, as well as political guests of honour. School groups danced, and a group consisting of villagers from various villages in Kavant subdistrict played the piha (a wind instrument similar to a recorder). Badva performed puja, two guests of honour spoke, and the BJP government touted its programmes for tribal welfare in order to contrast itself with the Congress Party (Interview with Prof. Shankarbhai Rathva, Chhotaudepur, 11 August 2018). While the Chhotaudepur celebration was envisioned as a local embodiment of an event rooted in a global institution - the U.N. - the Pavi Jetpur celebration was oriented towards the state and central governments, both in the hands of the BJP.

\section{State}

I first encountered World Adivasi Day not as a local but as a state celebration. In this context 'state' is not simply a political designation. In 1960 the Republic 
of India carved out the state of Gujarat on linguistic lines, so that here 'state' also refers to a shared language and to some extent a shared culture. The shared language links the adivasis of Gujarat - some 29 distinct communities - to one another. The celebration of World Adivasi Day is a good example. Although adivasis often speak their own languages, the medium of the Chhotaudepur celebration, both in the advertisements prior to the event and the event itself, was Gujarati. $^{29}$

As mentioned previously, I first learned of World Adivasi Day from Adilok, a bi-monthly magazine devoted to furthering tribal self-consciousness, unity, ${ }^{30}$ and rights. Since its founding in 2008 the magazine has been engaged in, to quote its publisher, "a campaign . . . to promote tribal identity through symbols like 9th August" (Personal communication, Vinayak Jadav, 5 May 2018). Over the years its coverage has become increasingly expansive. Recent July-August issues have contained a number of articles on World Adivasi Day, along with advertisements expressing felicitations for the occasion. September-October issues have generally contained news reports about celebrations along with photos sent in by 'correspondents' (not news professionals). For example, the back cover of the September-October 2018 issue contained a photo montage of celebrations at Ahmedabad, Ahva (the Dangs), Bhiloda (Aravalli district), Danta (Banaskantha district), Navsari, Sagbara (Narmada district), Surat, Vadodara, Vansda (Navsari district), and Vyara (Tapi district). Inside the magazine were four pages of reports on celebrations at Bhiloda, Danta, Mandal (Ahmedabad district), Morva Hadaf (Panchmahal district), Sagbara, Surat (two reports), Vadodara, Vansda, and Vyara, followed by a brief article on the state-wide seminar held at Gujarat University on the occasion of World Adivasi Day (A. Vasava 2018). Although Adilok has never reported on World Adivasi Day celebrations in Chhotaudepur, Chhotaudepur is not entirely absent. Both the 2017 and 2018 July-August issues featured full-page felicitations for World Adivasi Day on the back cover from Naranbhai Rathva, the member of the Rajya Sabha mentioned earlier, along with his son, Sangramsinh Rathva, until February 2018 mayor of Chhotaudepur.

Some participants in Chhotaudepur celebrations of World Adivasi Day have aligned themselves quite explicitly with state-wide units. For example, signs for the Jay Adivasi Mahasangh Gujarat are visible in photos that I received from the 2015 and 2016 celebrations, and at the 2018 celebration at least a few people wore shirts that identified them with the Mahasangh. Another state-wide group, the Rathsena, was present more subtly. Nor should we neglect the reports of Gujarati news outlets such as teersamachar.com, which carries news of interest to adivasis, and of posts before, during, and after the event on social media such as Facebook, Instagram, WhatsApp, and YouTube. Indeed, somewhat to my embarrassment, since my Gujarati is far from flawless, a portion of my own speech made its way to Facebook. ${ }^{31}$

In other words, many different state-wide non-governmental agents and media have contributed to the observance of World Adivasi Day in Gujarat, an observance to which the Chhotaudepur celebrations have varying connections. 
Since 2017 the state government, too, has been involved in the observation of World Adivasi Day, although its involvement is somewhat ironic: the government of India refuses to acknowledge that anyone living in India qualifies as indigenous in the U.N.'s sense of the term.

In 2017 the Department for Tribal Welfare decided that World Adivasi Day should be celebrated in the chief towns of all tribal sub-districts. Official responsibility for organising the Chhotaudepur celebration fell to the District Collector and the Deputy Superintendent of Police. On one account, at least, aside from the address that the Collector gave at the celebration, the government's involvement was limited to approving people to sit on the planning and implementation committees. The celebration itself was entirely organised by "Rathva [sic; not adivasi] leaders", and the organisers themselves bore the expenses. The government "did not give a single rupee" (Personal communication, Madhu Rathva, 6 May 2018; Shankarbhai Rathva, 18 May 2018). The government's involvement in 2018 was considerably more extensive. According to information that I received from Prof. Shankarbhai Rathva, the original idea was to hold a celebration in every electoral constituency. When it became difficult to find enough VIP guests of honour to go around, the government decided to sponsor celebrations in every district.

Understandably, there is resistance to and resentment of the state government's attempt to celebrate World Adivasi Day, certainly in Chhotaudepur and presumably elsewhere. Prof. Arjun Rathva, who regularly runs for office as a candidate of the Aam Aadmi Party, was quite clear that, in his mind, the celebration should only serve social purposes and that it should not involve any politicking, whether by parties in power or out of it. When I talked with Naranbhai Rathva (Congress Party) after the 2018 event, he agreed. World Adivasi Day celebrations, he told me, should be organised by tribals themselves, not by the government. Their purpose is to further tribal culture, lest young tribals forget it. On that day, he said, members of all parties should come together as one to celebrate. When I queried whether the celebration had any connection to the United Nations, he said no. It was a tribal celebration (Interview, Chhotaudepur, 12 August 2018).

\section{Regional - national}

A quick search on Google, YouTube, or Facebook is enough to show that Gujarat is not the only Indian state where people celebrate World Adivasi Day. For example, moving east from Chhotaudepur one finds World Adivasi Day celebrations in places such as Alirajpur ${ }^{32}$ and Indore. ${ }^{33}$ In fact, in 2018 the Madhya Pradesh government, unlike the government of Gujarat, declared World Adivasi Day an official holiday for people living in the state's tribal districts. ${ }^{34}$ Celebrations by non-governmental organisations have also transcended the borders of Gujarat. Perhaps the best examples are those of the Adivasi Ekta Parishad. In 2018 the Parishad celebration was held in Palghar, Maharashtra, roughly halfway between the southern border of Gujarat and the city of Mumbai. ${ }^{35}$ 
While these networks become less populated with greater distance, there are important respects in which the Chhotaudepur World Adivasi Day celebrations downscale regional or national elements. These include the various figures presented as heroes of the adivasi cause, especially Dr. B. R. Ambedkar (1891-1956) and even more so Birsa Munda (1875-1900). Both are represented by full-body statues at prominent places in Chhotaudepur town, and both appeared on the banners hung from the lampposts (see Figure 4.2). Both also featured prominently on the flyers announcing the 2017 and 2018 World Adivasi Day celebrations, and of the ten different billboard designs I saw in 2018, six contained portraits of Birsa, four of Dr. Ambedkar, always in the company of Birsa (see Figure 4.1).

Dr. Ambedkar's presence at the celebration is unmistakable, but it is also muted. He is widely known and respected as a leader of the Dalits, India's former untouchables. Some Harijans (as they are called in this area) do live in Chhotaudepur sub-district; they constitute $6.5 \%$ of the population Chhotaudepur town and about $3.25 \%$ of the population of the sub-district. Nevertheless, nothing in the use of Dr. Ambedkar's image for World Adivasi Day celebrations signalled solidarity between adivasis and Dalits - in legal terminology, between Scheduled Tribes and Scheduled Castes. Instead, inasmuch as Dr. Ambedkar was the guiding force behind the drafting of the Indian Constitution and of recognising Scheduled Tribes as a population with certain rights and privileges, he serves as a visual icon of the special legal status that adivasis enjoy. As we have seen, both the 2017 and 2018 flyers stressed that every Indian citizen, but especially every adivasi, has the responsibility to ensure that these rights and privileges are recognised and protected. Indeed, the flyers largely frame the World Adivasi Day celebrations as demonstrations of "the importance of our constitutional rights and their implementation".

Birsa Munda is a somewhat different figure. The flyer refers to him as a "Leader of the People and Martyr", while the banners strung up along the parade route refer to him as "Father of the Earth". In fact, Birsa serves as an icon of adivasi self-assertion and independent agency. An adivasi leader in Jharkhand - before adivasis were known as adivasis and Jharkhand was known as Jharkhand - he presented himself as a messenger from God. He advocated rejection of British rule and Christianity and a return to tribal ways. After a series of rebellious activities, he was arrested by the British in early 1900 and died in jail a few months later at the age of 25 (Singh 1983). The realities of transportation and communication being what they were in the late 19th century, especially in the princely state of Chhotaudepur (cf. Parmar 1903: 57, 178-179), it is a good bet that there were no contemporary connections between adivasis there, and Birsa and his movement.

In recent years, however, Birsa has come to play a prominent role in the selfconsciousness of adivasis in Chhotaudepur and elsewhere, not only in Gujarat but among adivasis in much of central India. One sign of his growing prominence is that on 30th June, 2017, a little more than a month before the 2017 World Adivasi Day celebration, a statue of Birsa was dedicated on the grounds of the newly 
built Nagar Seva Sadan (Municipal Services Centre) in Chhotaudepur. Birsa's great-granddaughter was present, along with her daughter. So was Sangramsinh Rathva, then Mayor of Chhotaudepur, and at least two other members of the 2017 World Adivasi Day planning committee, Dhulkiben Rathva and Prof. Shankarbhai Rathva (Rathva 2017). In both 2017 and 2018 the World Adivasi Day rally stopped at this statue. In 2018 various leaders of the community took turns hanging garlands of flowers on the statue, placing a tilak on Birsa's statue's forehead, and having their photos taken with the statue, while two lines of the rally processed around the statue and stationary crowds looked on (Figure 4.5).

This was the only place where the rally paused for ritual activities before arriving at the site of the formal programme.

In contrast to Birsa Munda and Dr. Ambedkar, one national symbol was conspicuously absent from the World Adivasi Day celebrations in Chhotaudepur in 2018 - and certainly from the photos I received of the 2017 celebration - namely, the tricolour, that is, the flag of the Republic of India. In 2018 there were muted allusions to the tricolour: green and orange were used as background colours, and I saw a couple of bows whose arcs were painted in three broad stripes (from top to bottom) orange, white, and green. Much more prominent, however, were red triangular pennants with a simple message, "Jay Adivasi" (see Figures 4.2 and 4.5). A comparison with the celebration held by the Congress Party in 2016 shows how much more could have been done. There the Indian flag was unmistakably present.

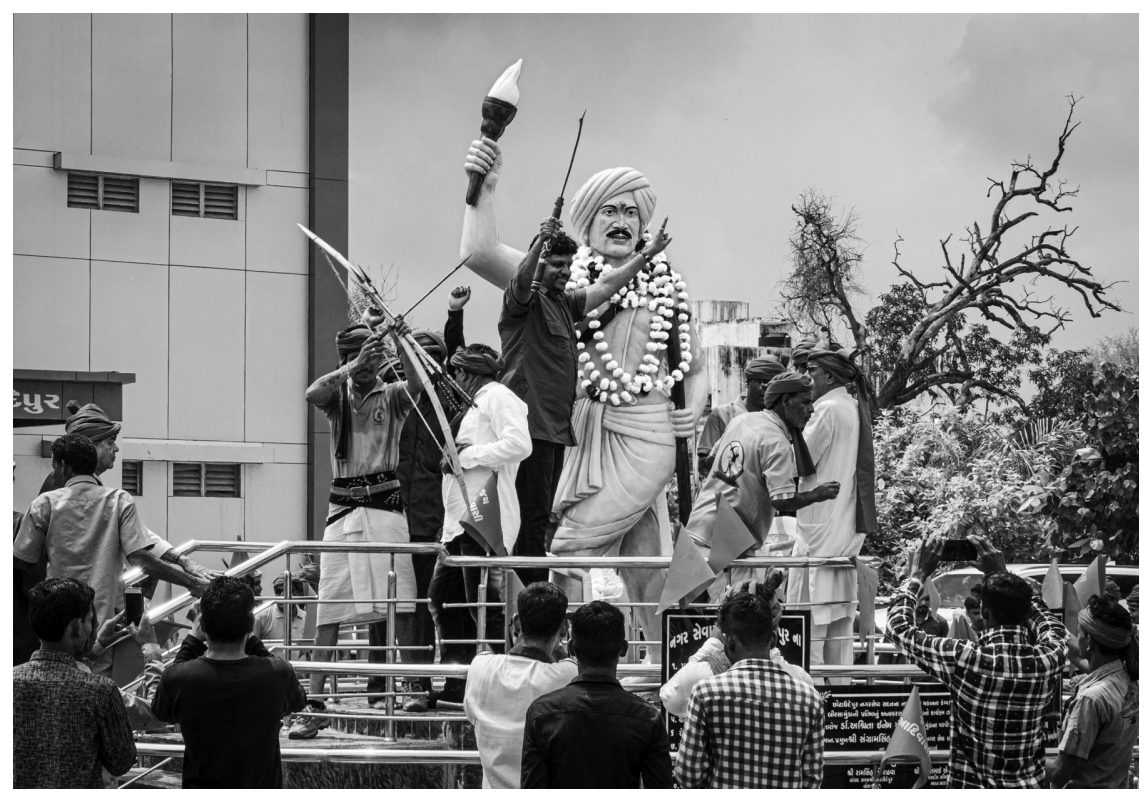

FIGURE 4.5 Felicitating the statue of Birsa Munda during the World Adivasi Day celebration, Chhotaudepur, 9 August 2018. 
The lack of symbols of the Indian nation does not necessarily signal alienation from the national government, as it might in other parts of India, where adivasis have engaged in covert and sometimes open revolt. ${ }^{36}$ Adivasis in Chhotaudepur live in an area where they are numerically and politically dominant. Indeed, elected officials from this area at the municipal, state, and national level are all required by law to belong to a Scheduled Tribe. Furthermore, adivasis in Chhotaudepur district freely employ the tricolour and other national symbols on other occasions, such as Republic Day. But World Adivasi Day is different. The images of Birsa and Dr. Ambedkar and the absence of symbols referring to the Republic as a whole underscore that World Adivasi Day does not celebrate the Indian nation or even the adivasi community as a loyal part of that nation. It celebrates adivasis as a specific community of local, regional, and national dimensions that enjoys its own distinctive constitutional rights and protections, rights and protections that the state and all of its citizens have the responsibility to further and protect.

\section{Transnational}

Since the rise of discussions of globalisation during the 1990s, the terms 'transnational' and 'global' (or 'globalising') have often appeared together and slid into one another. ${ }^{37}$ I use the term 'transnational' here to designate a spectrum upon which we may locate structures and events on any scale larger than the national. The term is not without its complications, especially in the context of discussions of indigeneity. On the one hand, the concept of indigeneity lay at the root of the Herderian concept of the nation; ${ }^{38}$ on the other, the indigenous is often conceived in contemporary parlance in terms of alienation from or marginalisation within the nation-state. For my purposes the term 'transnational' opens up a conceptual space within which to reflect on global indigeneity. In many ways global indigeneity is an imagined reality, but not one that is imagined consistently. The adivasis of Chhotaudepur imagine it one way. Other peoples whom the INREL project encountered imagine it differently.

For the most part, the participants in the Chhotaudepur celebration of World Adivasi Day, as realised on the ground in 2018, were local. Unlike in Pavi Jetpur, no representatives of the state or nation from outside the district were present, at least so far as I could determine. The only videsi (foreign) participant that I know of was me. The local participants with whom I spoke share this impression.

It would nevertheless be a mistake to conclude from these observations that adivasis in this part of India have no transnational connections. In January 2018, the Adivasi Ekta Parishad held its 25th annual cultural festival in Rajpipla, some $72 \mathrm{kms}$ as the crow flies southwest of Chhotaudepur. According to media reports it attracted 500,000 participants, including from several other countries, among them Nepal, Indonesia, and Australia. ${ }^{39}$ In April 2018 a delegation from the Parishad visited the meeting of the U.N.'s Permanent Forum on Indigenous Issues (S. Vasava 2018). At the time of the 2018 World Adivasi Day celebration, the Adivasi 
Academy in Tejgadh, located in Chhotaudepur sub-district $10 \mathrm{kms}$ to the west of Chhotaudepur town, was in the midst of a district-wide UNICEF-sponsored child welfare study. It was also hosting two (non-indigenous) German interns who were about to leave after a year in residency. More broadly, the Academy has hosted international conferences and exhibitions as well as a number of foreign researchers, myself included. In 2016 it brokered a deal in which Cambridge University's Museum of Archaeology and Anthropology commissioned two sculptures from Balubhai Rathva, an artist from Ganthiya village (Chhotaudepur sub-district). ${ }^{40}$ But while adivasis in the area may have these transnational connections, they were not actualised in the participants in the 2018 World Adivasi Day celebration, myself excepted.

The transnational did, however, put in appearances. The most visually prominent way was the use of the U.N. symbol. It appeared on the backdrop of the stage - at least in 2017; it was omitted in 2018. It appeared on the flyer advertising the celebration, even though the 2018 flyer omitted the 2017 flyer's account of the international proceedings that established the day. It featured on the paper badges that the celebration's organisers wore. It also figured on three of the ten different billboard designs that I identified. In this regard, one billboard particularly caught my attention. Its background featured the U.N. symbol on an (Islamic) green field, without a hint of Hindu saffron or icons of adivasi identity. In effect, this billboard downscaled a recognisable icon of cooperation between nations to serve as an instrument for overcoming communal division. It read, "Silver Spoon plaza - on the occasion of World Adivasi Day the entire Muslim community along with Commercial Stone Vanar and Babadev Mining Dadigam sends its heartfelt best wishes to [our] adivasi brothers and sisters". ${ }^{41}$

Billboards and speeches at the formal programme occasionally referred to the United Nations and to the celebration as 'international' and 'global' (see Figure 4.1). But as with the 2017 flyer's silence about UNDRIP, the celebrations contained little specific reference to the U.N. as an actual international agency or to its programmes. ${ }^{42}$ What seemed to count was the idea of the U.N. as an instrument of legitimation, as a higher authority than the nation-state. More subtly transnational in its resonance was the trope, common in international discourse, that indigenous people live in harmony with nature, unlike their more 'developed' neighbours. One finds this trope in both the 2017 and 2018 flyers, but the backdrops on the stage welcoming people to the 2017 and 2018 formal programmes gave it a pointedly Spinozean twist, as did one billboard. They read, Prakrti ej parameśvār, "Nature - this is the highest god".

\section{Imagining global adivasi-ness}

The Chhotaudepur 9th August celebrations translate the conception of an imagined global indigeneity into an imagined global adivasi-ness. One sees this already in the first two words of the text from the flyers: Viśvanā àdivāsīo-, "the adivasis of the world". The transformations that result should not be overlooked. 
It is customary to observe the difficulty of making adivasis fit into the international indigenous mould. For example, Megan Moodie writes that it takes "a good deal of work . . . to make 'adivasi' equivalent to the international language of "indigenous people"' (2015: 190, n. 12). Such a statement, however, grants a certain privilege to international discourse - or rather, to a certain discursive community by virtue of assigning to it the privilege of constituting 'international discourse'. I want to reverse this statement and make adivasi the ultimate reference point instead. ${ }^{43}$ In a scholarly or legal context, it takes a good deal of work to make Native Americans, First Nations peoples, native Hawaiians, Sámi, and Maori equivalent to adivasis; nevertheless, this is the way adivasis in the Chhotaudepur area unreflectively think about them. Crucial to the celebration of World Adivasi Day is the imagination that there are adivasis throughout the world, and that they are all in fact engaged in the same celebration.

This imagination is not entirely mistaken. Consider activities that took place in 2018 from two areas involved in the INREL project: Sápmi and Costa Rica. ${ }^{44}$ On 9th August Alii Keskitalo, the President of the Norwegian Sámi Parliament, issued a statement in both Sámi and Norwegian that recognised the U.N.'s International Day of the World's Indigenous Peoples; her focus was on the importance of the Sámi language and the promotion of 2019 as the International Year of Indigenous Languages. ${ }^{45}$ In Tromsø the Library and City Archive sponsored an activity that highlighted the transnational nature of the day in a manner particularly suited to the INREL project: a launch of the book $A$ Naga Odyssey, by Visier Meyasetsu Sanyü with Richar Broome, at which both Visier and Jon Petter Gintal, a member of the Norwegian Sámi Parliament, spoke. ${ }^{46}$ Also in Sápmi, Isogaisa, an annual festival of Sámi and indigenous culture, began on 9th August in 2018, although the organiser, Ronald Kvernmo, told Siv Ellen Kraft that any correspondence of the start of the festival with the date of the U.N.'s International Day was purely coincidental - to the extent that coincidences exist at all (Personal communication, 11 August 2018). Meanwhile, in Costa Rica 9th August provided an occasion for politicking. The Costa Rican government used the occasion to announce the initiation of a process for establishing a Public Policy for Indigenous Peoples, 2019-2024. ${ }^{47}$ Frenapi - the National Front of Indigenous Peoples, which unites representatives of the Cabécares, Bribris, Teribes, Ngöbes, and Ngöbes Bugle - issued a statement of its own. ${ }^{48}$

Despite these transnational manifestations, World Adivasi Day is not really a global celebration. People in the United States, for example, whether indigenous or not, seem to pay little attention to it. Instead, the second Monday in October - a convenient substitute for 12th October, the day when Columbus and his crew first sighted American land - is being increasingly celebrated as Indigenous Peoples' Day. ${ }^{49}$ The various U.S. Indigenous Peoples' Day celebrations include a variety of activities, among them marches and cultural programmes similar to those in celebrations of World Adivasi Day in Gujarat. ${ }^{50}$ Some of these events imagine a global celebration, too, although of course the second Monday in October - or 12th October, for that matter - does not have any meaning 
for adivasis in Gujarat. One example is the screening of the film "The Condor and the Eagle", which addresses environmental issues and depicts, among other things, a ceremony held on Indigenous Peoples' Day (10th October), 2016, at the site of the Standing Rock protests to the Dakota Access Pipeline. Many screenings took place in the U.S., but at least one screening took place elsewhere, too: Siv Ellen Kraft, principal investigator of the INREL project and contributor to this volume, arranged a screening in Tromsø, Norway, that included a virtual interview with the filmmaker.

Another example of the transnational extension of the U.S. Indigenous Peoples' Day, and one that is more clearly global in its framing, is the Global Indigenous Wisdom Summit, a cyber-summit held via Facebook on Monday, 8th October, 2018. Although the programme advertised the involvement of "keepers of wisdom from around the world", only one of the keepers listed on the website, Moetu-Taiha Ransfield, came from outside the Americas, in her case from Aotearoa/New Zealand. Most live in North America, although bio blurbs often emphasise their global activity. ${ }^{51} \mathrm{~A}$ similar pattern appears in the archived talks available on the Global Indigenous Wisdom Summit website. There one encounters 22 speakers from North America (if we include one speaker from Greenland), 11 speakers from Latin America, and two from Uganda. ${ }^{52}$ The closest one gets to South Asia is Mikuak Rai, who seems to have South Asian interests, but these interests are difficult to judge from web searches. At least at the time of writing, Rai's Instagram posts from India concentrated on typical tourist destinations and had no discernible adivasi content. What hints there are of his working with the marginalised in India have more to do with Dalits (the former untouchables) than with adivasis. ${ }^{53}$ Even more curious is the online context of the Global Indigenous Wisdom Summit. In 2018 the Summit was broadcast on the Facebook site of the Shift Network. ${ }^{54}$ Here proponents of indigenous wisdom with a decidedly American slant hobnob not with representatives of tribal peoples of South Asia but with people purveying the wisdom of the adivasis' historical oppressors - perhaps because their knowledge of South Asian history and society is slim and because they conceive of indigeneity according to what some call the 'saltwater theory': any victim of European colonisation, whether of the settler or administrative variety, counts as an indigenous person (Uddin, Gerharz, and Chakkarath 2018: 12; Baird 2018: 50, 60). Such a view completely misses the social condition - and in fact the existence - of adivasis such as Rathvas.

12th October - or the second Monday in October - is not the only alternative to 9th August as a day for celebrating indigeneity. For example, according to one source, although both days are celebrated in Costa Rica, few indigenous people there may actually be familiar with the U.N.'s International Day (9th August), and because the 12th October holiday is often shifted to the Monday after 12th October (rather than the second Monday in the month), it provides many Costa Ricans with the opportunity for a long holiday weekend but has little meaning for many indigenous people, who, as agriculturalists, generally cannot afford to take the time off. The most important day for celebrating 
indigeneity in Costa Rica may well be 19th April, known as 'Costa Rican Aboriginal Day' or 'The Day of the Indigenous'. (This date, too, has a transnational dimension; it is celebrated in Brazil as the Dio do Indio.) Of more local importance is 4th July, a day important for the indigenous people of Talamanca because it is the date on which Pablo Presbere, the leader of indigenous Talamancan resistance to colonisation, was killed in 1710 (Personal communication from Heidi Mayorga Escalante, 11 January 2018).

My purpose here is not to criticise adivasis in Chhotaudepur for imagining that there is a global adivasi population celebrating World Adivasi Day. Indigenous people are hardly alone in imagining that their celebrations are universal when strictly speaking they are not. For example, people who use the Gregorian calendar often imagine that the entire world celebrates New Year's Day on 1st January. Of course, at the present these latter societies exercise transnational economic and political force and cultural hegemony in a way that adivasi societies do not. Thus, celebrations on the night of 31st December are becoming increasingly widespread, even in places like Chhotaudepur, where 31st December and 1st January remain workdays. But rather than explore these differentials of power and their consequences, which on the surface, at least, seem rather obvious, I want to explore a little more themes that are closer to the INREL project: the translation via performance of the U.N.'s International Day of the World's Indigenous Peoples as World Adivasi Day, and the translation of indigenous religion(s) as adivasi religion or dharam.

\section{Translation in performance}

For many indigenous people, a principal issue is sovereignty. Among people visited in the INREL project, native Hawaiians are a good example. ${ }^{55}$ So are the Nagas in Northeast India (cf. Longkumer, Chapter 3; more generally Mukherji 2013: 124). At least at the time of writing, however, sovereignty issues have had little traction among Rathvas. A small minority in and around Gujarat is interested in establishing a separate adivasi state known as Bhilistan - the land of the Bhils - within the Indian Republic, but in 2018 a different issue had much greater significance: identity, both adivasi identity generally and Rathva identity specifically. ${ }^{56}$ Here are the high points.

On 14th January, at the gathering of the Adivasi Ekta Parishad in Rajpipla, Gujarat's Minister for Tribal Welfare, Ganpat Vasava, was booed, pelted with stones, and forced to flee. His alleged offence was threatening tribal identity by suggesting that the category 'Scheduled Tribe' (ST) be broadened to include more communities. ${ }^{57}$ On 9th March the Rathva community effected a complete bandh - a commercial and public shut-down - of Chhotaudepur district in protest against efforts, started farther north, to have them re-classified not as tribal but as belonging to the 'Other Backward Classes'; those efforts, if successful, would have deprived the Rathvas in Chhotaudepur district of political representation and employment, since political offices and some government jobs 
there are reserved for persons belonging to Scheduled Tribes. On 10th June, at a meeting in Pavi Jetpur, the Rath Sena - the 'Rathva Army' - was founded to further Rathva causes; among its 13 stated objectives are achieving "a permanent solution to questions that have been raised about the identity of the Rathva community" and "establishing a global identity for Rathva culture", for example, by acquiring a GI tag for Pithora paintings and promoting the Kavant gerno melo (a large festival) as an opportunity for national and international tourism. ${ }^{58}$ From 30th August to 2nd September the Don Bosco High School in Chhotaudepur hosted a public programme, involving both adivasi and non-adivasi speakers and aimed at preserving tribal culture and identity. On 21st October Rathva politicians from across the political spectrum gathered in Chhotaudepur and signed a pledge to boycott all political parties until the question of Rathva identity was solved once and for all. ${ }^{59}$ Later, adivasis across the state called for a complete, statewide bandh on 31st October, the day on which Prime Minister Narendra Modi inaugurated the 'Statue of Unity', that is, a statue of the Gujarati leader Sardar Vallabhbhai Patel located in the middle of the area from which adivasis have been displaced by the Sardar Sarovar dam (on the dam, cf. Baviskar 2004). Finally, on 28th December Ganpat Vasava, still Minister for Tribal Welfare, appointed a six-person committee to examine the ST status of Rathvas. In response, on 30th December, at a gathering of the Rathva Adivasi Samaj Mahasabha in Kavant, the attendees, reported to be 5000 persons, resolved to boycott all political parties and activities until the issue of identity was resolved. ${ }^{60}$

Clearly, identity is a current issue among Rathvas, and one that the enthusiasm with which adivasis in Chhotaudepur have embraced World Adivasi Day celebrations articulates. ${ }^{61}$ In doing so, they have employed patterns that transcend purposive, ethnic, geographical, political, religious, and perhaps historical boundaries. One sees some resonance with the protests at Alta, Norway, in the late 1970s and early 1980s, in the protests against the Thirty Meter Telescope on Mauna Kea, Hawai'i, that began in 2014, and in the protests against the Dakota Access Pipeline at Standing Rock in 2016 and 2017. In form, however, the celebration of World Adivasi Day more closely resembles Nazi Party rallies, Corpus Christi celebrations (in places where there are public processions with a monstrance followed by a Mass), protests against the American invasion of Iraq in Washington, D.C., in 2003, and gay pride parades. To say the least, this is a disparate set of events, politically and culturally. Nevertheless, each involves marches through an urban area, followed by speakers on a stage.

Before I participated in the 2018 Chhotaudepur celebration of World Adivasi Day, I was under the impression that the formal programme of awards and speeches was the core of the celebration and that the rally was simply prefatory. This is also the way at least one news report represented the 2018 event. ${ }^{62}$ I now think, however, that this impression is mistaken. For most of the people involved, the rally was the more important component. It provided adivasis with an opportunity to revel in public: to wear traditional adivasi clothes that one might not ordinarily wear; ${ }^{63}$ to wave traditional adivasi weapons that one might 
not ordinarily carry; to march and dance as an adivasi with fellow adivasis; to mark with one's presence - indeed, to occupy - public streets and spaces; to render adivasi-ness visible; to make it audible with music, whistles, ululations, and repeated shouts of “Jay Johar! Jay Adivasi!"; to feel one's adivasi-ness in one's muscles and one's movements and one's bones; and to identify with it, take pride in it, share it on social media, in short, to make adivasi-ness and one's own adivasiness unmistakably, inescapably, irresistibly present.

One recent attempt to theorise this kind of public presence has been developed by Judith Butler (2015). Engaging with the thought of Hannah Arendt (cf. 1998 [1958]), for whom politics consisted of words spoken rationally by free men in public assembly, Butler stresses that politics can take place simply through bodies appearing in a public space, before any words are spoken. Indeed, she notes that "the gathering signifies in excess of what is said" (Butler 2015: 8).

Butler is largely reflecting on events in the early 2010s, and she has certain movements in mind: Tahrir Square and the Arab Spring, the Occupy Movement, and, of course, resistance to cis- and heteronormativity in matters of gender. Although she herself focuses on movements that, in contrast to Arendt's assembly, arise from social precarity, she recognises that the power of corporeal public presence is hardly limited to these. She writes, "There are, after all, all sorts of surging multitudes . . . and they would include lynch mobs, anti-Semitic or racist or fascist congregations, and violent forms of antiparliamentary mass movements" (Butler 2015: 183; cf. 19 for assemblies orchestrated by the state, also 124). She also notes that "no one assembly can rightly become the basis for generalizations about all assemblies" (Butler 2015: 155). And referencing Bruno Latour and Isabelle Stengers, she wonders whether "negotiating the sphere of appearance is . . . one of the investigative capacities of the organism" (Butler 2015: 87). To my mind, this conjecture is too academic, too oriented to the cognitive, at least as far as the Chhotaudepur rally and assembly for World Adivasi Day are concerned. I would rather attribute marching through the streets and assembling in the public square to a human and more broadly animal propensity to claim and signal ownership of territory by moving through and occupying it.

There is much in Butler's account that resonates with the Chhotaudepur celebration of World Adivasi Day. For example, she draws our attention to the significance of assembling in cyberspace as well as in physical space: "The streets and the square are not the only way that people assemble, and we know that social networking produces links of solidarity that can be quite impressive and effective in the virtual domain" (Butler 2015: 153). Yet there are also significant differences, and they may help to sharpen our focus. For example, it is understandable that someone concerned with events at Tahrir Square during the Arab Spring as well as with the Occupy Movement would envision agents of state power as physically opposed to the assembled: "Heightened bodily exposure happens when assemblies deliberately expose their bodies to police power on the street or in public domains" (Butler 2015: 125). But such was not the case at the Chhotaudepur celebration of World Adivasi Day, where police accompanied 
the rally (see Figure 4.3) and generally facilitated it by managing traffic. So far as I could see, the rally provoked no opposition and required no protection. Butler also purveys a view of universal mutual interdependence: "The opposite of precarity is not security, but, rather, the struggle for an egalitarian social and political order in which a livable interdependency becomes possible" (Butler 2015: 69). World Adivasi Day may or may not have egalitarian implications, but it is not a celebration of the interdependence of adivasis with the greater Indian community; it is a celebration of adivasi independence and distinctiveness. Furthermore, a central division in Butler's analysis, perhaps derived from Arendt, is the division between the private and the political; such a division would seem to leave little room for what some saw as the salient distinction between the Chhotaudepur celebration of World Adivasi Day and the government-sponsored celebration in Pavi Jetpur: a distinction between two public realms, the political, which is necessarily divisive, and the social, which is preferably unitive and apolitical. Perhaps most importantly, Butler's analysis rests firmly within the European-American tradition of political theory. She invokes both the ideal of unity that one finds embodied in the U.S. Constitution - 'We the People' (the title of her fifth chapter) - and the assertion of the right to freedom of assembly under international law. I happen to cherish these ideals, too, but they do not capture the spirit of World Adivasi Day. In that celebration unity is not the unity of 'We the People' - the parity of all as citizens of the state - but of Ame adivasi chhie, 'We are adivasis' - the unity of all adivasi peoples everywhere, not just in one particular nation-state: "One arrow, one bow; all adivasis are equal and one". It is in this sense that the Chhotaudepur celebration of World Adivasi Day is indeed a celebration of imagined global adivasi-ness.

\section{Where's adivasi religion?}

Translation transforms the U.N.'s International Day of the World's Indigenous Peoples into World Adivasi Day. It also transforms the category 'indigenous religion(s)'. ${ }^{64}$ One could translate this phrase as Adidharam, the first, primal, or original dharam (dharma), as in the German Urreligion. Such a translation has both antiquarian and normative connotations: it is the religion that existed at the beginning of time (whenever that happened to be) and the religion proper to a group of people identified with those first people (cf. Munda 2000). Unfortunately, such a translation does not help in making sense of the diversity of "dharmik and other private convictions" that the World Adivasi Day flyers ask people to leave at home. A better translation, at least in the present context, would be Adivasi dharam, the dharam of adivasis. Unlike the English word 'indigenous', however, the word adivasi, whether used as a noun or an adjective, always refers to a group of people who, in whatever social imaginary is operative, are conceived of as first inhabitants. In this case Adivasi dharam could refer to the traditional dharam of adivasis, that is, the dharam of jagats. An analogy would be the phrase adivasi bhasha, 'adivasi language', used to identify the language spoken 
exclusively by adivasis, in contrast to a language spoken more broadly, such as Gujarati or Hindi. Given the dharmik diversity that the flyers envision, however, I would rather take adivasi dharam as referring to whatever dharams adivasis happen to adhere to, whether these dharams are jagat, Hindu, Muslim, Christian, Jain, Sikh, or some other. All of these constitute the private dharmik beliefs that are to be excluded from the Chhotaudepur World Adivasi Day celebration.

Of course, one can always raise questions about the extent to which dharam is an exact synonym for religion (Alles 2013), but there is no need to determine that extent here. Let us simply say that whatever else dharam may or may not include, in the present context it involves beliefs concerned with extraordinary beings (devs, devis, ancestors, Bhagwan, God) or - to accommodate bhagats who do not think in theistic terms - an ultimate source underlying all reality, such as the atman (self). Both types of belief are seen locally as dharmik. But dharam is not just limited to beliefs. It also involves practices such as rituals, persons such as ritual leaders, material objects associated with these practices and leaders, and probably other things as well.

Despite what the flyers request, the Chhotaudepur World Adivasi Day celebration does not actually exclude all dharmik beliefs. One belief survives, presumably because it is widely seen as constitutive of the adivasi lifestyle, as it is of the global indigenous worldview: nature is the highest Lord. The flyers do, however, single out dharmik beliefs for special mention. They say nothing about practices, persons, or material objects, and in actual practice at the celebration, these elements are treated as separable from beliefs. If one sets aside beliefs associated with traditional practices, persons, and objects, along with beliefs that favour alternative practices, persons, and objects, and if traditional practices, persons, and objects do not offend the sensibilities, moral or otherwise, of a large segment of the community, as meat eating and alcohol consumption do, then these practices, persons, and objects can be transformed. Instead of being components of a specific dharmik complex, they become cultural markers distinctive of the community as a whole. To judge from the example of Chhotaudepur, material objects seem to be particularly open to this process of 'de-semantization', although this is not always the case (cf. Longkumer 2018). Pithoras, glazed, stylised terracotta horses, dhabus, oil lamps set atop piles of paddy, tipna, tied red threads (see Figure 4.4) these no longer function in efforts to communicate and maintain relationships with devs, devis, and ancestors, as they do in jagat traditions. When these objects are divested of particular religious meaning, bhagats, Jains, Christians, and all other adivasis can, and in Chhotaudepur do, embrace them as distinctive markers of adivasi culture and identity.

Inspired especially by the work of Grace Davie (1994), scholars of religion in Western Europe and North America have frequently made a distinction between believing and belonging: certain groups of people have a penchant for religious or spiritual believing without feeling a need to belong - often phrased in Christian terms as belonging to a church (Davie 1994). Like any binary, this one, too, is capable of inversion, although a quick search for the phrase "belonging 
without believing" turned up only the use of the phrase for theological purposes: as a phrase denoting people whose intellectual commitments make it difficult for them to assent to traditional Christian teachings but who nevertheless belong to and participate in Christian churches, their participation providing some sort of access to a transcendent (Mountford 2011: 7; cf. Shaw 2008; both Mountford and Shaw cite Taylor 2007).

The Chhotaudepur celebrations of World Adivasi Day present a case of belonging without believing, too, but in a very different sense. For adivasis in Chhotaudepur the challenge is not intellectual but social, and what one belongs to is not a specific religious community but the adivasi community, regardless of what one's dharmik beliefs and loyalties might happen to be. In this way, adivasi religion provides the organisers of World Adivasi Day with powerful means to create a sense of belonging. In presenting beliefs as private matters, they divest religious elements, especially material ones, of their connection with divisive factors. In the process they aestheticise, secularise, and 'heritage-ise' them as markers of adivasi identity.

The INREL project has observed that in some cases the sense of a shared religious perspective facilitates transnational links between various indigenous communities (Johnson and Kraft 2018). This is one reason for the parenthetical 's' in the phrase 'indigenous religion(s)'. In other cases, however, people are forced to negotiate local religious diversity and division (e.g., Longkumer 2018). The latter is the case in the Chhotaudepur area. Especially given the tensions between jagats and bhagats, World Adivasi Day celebrations in Chhotaudepur can hardly embrace religion in toto and remain fully inclusive. ${ }^{65}$ They have, however, been able to disaggregate the various components of traditional religious complexes by classifying specific religious commitments as private beliefs and convictions. Doing so has freed some persons and practices (but not all practices, such as animal sacrifice) to function as general cultural markers. It has especially done so for material objects. Such markers contribute to the agenda of the World Adivasi Day celebration: to celebrate, protect, and further adivasi-ness.

Acts of translation are acts of transformation and creation, and the translation of the U.N.'s International Day of the World's Indigenous Peoples into the celebration of World Adivasi Day at Chhotaudepur is no exception. Part of that translation is finding significance in global adivasi-ness: in recognising that, to whatever extent some in 'mainstream' society may marginalise adivasis as 'backward' and in need of 'civilisation', adivasis belong to a group of peoples spread throughout the globe, a global Gemeinschaft - a community or family - of peoples who are important enough to be recognised and celebrated by the premier global institution of our time, peoples - in the eyes of some Rathvas - upon whose cultures all civilisations have been built and upon whose ability to live in harmony with nature the very fate of the planet may well depend. For the moment, at least, this global network is mostly imagined. Like the INREL project itself, few if any indigenous people from other parts of the world have shown any interest in visiting or establishing relations with the adivasis of Chhotaudepur. 
The actual transnational networks that exist are largely populated by interested and sympathetic non-indigenous persons, like myself, and they have often been carefully managed by institutions, such as the Adivasi Academy in Tejgadh, that are ultimately under non-adivasi control. Nevertheless, however imagined the global adivasi-ness of the Chhotaudepur celebration of World Adivasi Day may be, its consequences in the lives of the participants - the pride it gives, the unity it promotes - are very real. To quote a Rathva friend, a retired government employee whose health precluded participation in the 2018 World Adivasi Day celebration:

For adivasis like me the celebration of this day is a matter of extremely great pride. Knowledge of adivasi culture will spread throughout the entire world. The traditions and customs of adivasi society are different from those of other societies. What is especially good is one-ness $(e k t \bar{a})$, unity. Everyone comes together to make this festival, this celebration.

(Personal communication via WhatsApp, 10 May 2018)

\section{Notes}

1 Special thanks to Prof. Vinayak Jadav (St. Xavier's College, Ahmedabad), Prof. Subhash Ishai (S.N. College, Chhotaudepur), Prof. Arjun Rathva (M. C. Rathwa Arts College, Pavi Jetpur), Dashrath Rathva (Kocvad and Chhotaudepur), Madhu Rathva (Vanar), Najroo Rathva (Devhant), the Hon. Naranbhai Rathva (Chhotaudepur), Naranbhai Rathva (Tejgadh), Prof. Shankarbhai Rathva (S.N. College, Chhotaudepur), Vipul Rathva, and Prof. D. B. Vadera (S.N. College, Chhotaudepur).

2 In 2018 a similar flyer was distributed, but the text of this paragraph was truncated: "In order to ensure that adivasis throughout the world receive human rights, and on behalf of their way of life, knowledge traditions, and human development, was [sic] made in 1993 by the United Nations (UNO). And after that, starting in 1994, the 9th of August has been celebrated in all the world as World Adivasi Day. For us it is also a matter of pride that the year 2019 has been designated by UNO as Adivasi Language Year". According to Prof. Arjun Rathva, possibly the principal author, the text was shortened because people were not really interested in reading so much detail.

3 www.un.org/geninfo/bp/enviro.html accessed 28 April 2018.

4 www.un.org/en/events/indigenousday/background.shtml accessed 28 April 2018.

5 Panchayats (Extension to the Scheduled Areas) Act, 1996; cf. https://pesadarpan.gov.in/ en_US/home, last accessed 14 October 2019.

6 "Religion" is, in fact, the way local English-speakers (who are all multilingual) refer to dharma. I have checked my entire translation with locals, and any translation of dharmik besides "religious" would strike them as wrong.

7 The flyer distributed in 2018 preserved this text more or less intact, replacing the words "let us, too, full of pride and with great ceremony, demonstrate the importance of our constitutional rights and their implementation and of the development of our community", with the shorter and more poetic expression, "let us take up the beat" (as in rhythm).

8 In terms developed by Holbraad and Pedersen (2017: 127), following Marilyn Strathern, the concern here is primarily with quantitative scales, although to the extent that politics and religion constitute two separate domains, it may also be at times implicitly qualitative.

9 MPs and MLAs in this area are required by law to belong to a Scheduled Tribe. 
10 In 2017 all nine members of the planning committee as well as all five members of the programme committee were Rathvas. In 2018 there was one Dhanak among the 23 members of the local planning committee; all the rest were Rathvas.

11 Cf. www.counterview.net/2015/09/south-gujarat-tribal-rebellion-spreads.html, accessed 18 August 2018.

12 www.facebook.com/298584443572626/videos/374411179296626/ uploaded 14 August, 2012

13 The celebration was held in the village of Vasedi just north of Chhotaudepur municipality. To judge from a banner displayed at the event, it was held under the auspices of the Chhotaudepur sub-district chapter of the Jay Adivasi Mahasangh Gujarat.

$14 \mathrm{http}: / /$ indianexpress.com/article/india/india-news-india/with-eye-on-polls-congressto-hold-rallies-in-tribal-areas-2962899/ Accessed 9 June 2018.

15 Personal communications from Madhu Rathva, 6 May 2018, and Shankarbhai Rathva, 4 May 2018, respectively.

16 According to the 2011 Census the Scheduled Tribes population was 6377; http:// censusindia.gov.in/pca/pcadata/DDW_PCA2419_2011_MDDS\%20with\%20UI.xlsx, last accessed 16 October 2019.

17 For a portion of the rally, see https://youtu.be/2rYiYRPB1aw, last accessed 16 October 2019.

18 For an example of the cultural performances see https://youtu.be/_36Z5Pt79AE, last accessed 16 October 2019.

19 In a 16-hour period on 8th August Kavant taluka received $346 \mathrm{~mm}$ (13.6 inches) of rain. On the same day Pavi Jetpur and Chhotaudepur talukas received $264 \mathrm{~mm}(10.4$ inches) and $139 \mathrm{~mm}$ (5.5 inches) of rain, respectively - and the rains continued. See "Kawant pounded by 346mm in 16 hours", Times of India, 9 August 2019, https:// timesofindia.indiatimes.com/city/vadodara/kawant-pounded-by-346mm-in-16-hrs/ articleshow/70595555.cms, last accessed 14 October 2019.

20 The backdrop at the 2018 celebration was similar in design, but it lacked the U.N. symbol, apparently a decision made by the artist, Lakshmanbhai Rathva.

21 The only exception that I saw was a sign expressing World Adivasi Day felicitations erected by the Chhotaudepur Nagar Seva Sadan (municipal services centre); 13 of the 29 faces on that sign were of women.

22 My claims about 2017 are based on documentation of the event by a professional photographer.

23 For (hyper)masculine displays in other indigenous contexts, see, e.g., Hokowhitu (2014) and Tengan (2014).

24 I, too, was often asked to hold weapons when I appeared in selfies - an act of solidarity but also, one suspects, of affirmation from an outsider.

25 A similar complexity of scales is noted in many of the chapters in Gerharz, Uddin, and Chakkarath (2018). Holbraad and Pedersen note that movement from the individual to the global does not entail a change in complexity. As they write, "The potential for complexity remains constant no matter what the scale" (Holbraad and Pedersen 2017: 124). Similarly, Joanna Cook, James Laidlaw, and Jonathan Mair: "We do not change the quantity or detail of the data we encounter merely by changing scale; we simply encounter different details"; cf. Cook, Laidlaw, and Mair (2009: 56-57). Both are developing points made by Marilyn Strathern (2004: xiii-xxv); cf. "similar intellectual operations have to be performed on the data whatever the scale - classification, composition, analysis, discrimination, and so forth" (xv), and "The idea of perspective suggests one will encounter whole fresh sets of information as one moves through various scales - from organism to cell to atomic particle, from society to group to individual" (xix).

26 I borrow this phrase from Anthony Giddens (e.g., 1990: 14-21, 63-65), without adopting his distinction between premodernity and modernity.

27 An advocacy group; the name literally means "Rath army".

28 I asked Arjun Rathva, the principal author of the text, whether he thought he might have picked up the idea of private beliefs during his M.A. studies at the University of 
Leeds. He replied that this suggestion was ludicrous; it had nothing to do with what he was studying. Conversation with Arjun Rathva, Chhotaudepur, 8 August 2018.

29 With one exception. After I spoke (mostly in rough Gujarati), the former mayor of Chhotaudepur, Sangramsinh Rathva, addressed me directly from the podium in English.

30 Akhạ̣ditatā, literally, "indivisibility".

31 Cf. https://m.facebook.com/story.php?story_fbid=2085134648204477\&id=10000123 8868580 , posted by Sangramsinh Rathva.

32 https://youtu.be/FaflbtZi3HI

33 https://youtu.be/m9Hjp-xxjoM

34 https://naidunia.jagran.com/madhya-pradesh/bhopal-government-holiday-for-thefirst-time-on-the-world-tribal-day-in-20-districts-of-the-mp-1842557

35 www.facebook.com/aep.mh/photos/a.582469901873108/1748733275246759/?type= 3\&theater

36 The literature is immense. For one attempt at analysis, see Mukherji (2013), especially 118-124.

37 E.g., Mark-Anthony Falzon (2009): 6 refers to transnationalism as the "cousin" of globalisation. See further the talk of transnational connections in terms of a global ecumene in Hannerz 1996 (the concept is introduced on p. 7) and www.transcomm.ox.ac.uk/ introduc.htm. "Transnational" is an older term, dating from the 1960s, but at least in the Google Ngram database it was eclipsed in prominence by "globalization" in 1997.

38 I do not mean to claim that Johann Gottfried Herder (1744-1803) actively employed our contemporary conception of indigeneity. He did, however, conceive of the Volkthe nation or ethnic group - in terms of a distinctive conjunction of language, thought, culture, religion, and habitat, undistorted by cosmopolitan education. Cf. Ulrich Gaier 2009: 169: "For Herder . . . each language - and accordingly each mythology - is intimately linked to the character of the nation where this language is spoken. . . . The mother tongue lays the foundation of our cognition of the world, of our sensibility and reasoning, because language and mode of thinking are intimately linked. . . . At the basis of this process of the formation of language, thought, and mythology is the Volk, the people, in Herder's use of the word the mass of simple men and women who are not deformed by civilization". This view lay at the heart of various 19th century nationalistic disciplines of folklore studies, for example, in the Baltic region, and informed various European movements of national awakening.

39 www.dnaindia.com/india/report-fight-for-rights-5-lakh-tribals-to-gather-in-gujarat2575219. Information at hand does not specify whether the attendees from Indonesia and Australia were native Indonesians and Australians or adivasis who had emigrated and were now returning for the celebration.

40 http://adivasiacademy.org/chhotaudepursculptureatcambridge.aspx, https://timesofindia. indiatimes.com/city/vadodara/tribals-artwork-adorns-uk-museum/articleshow/ 56117792.cms. The Adivasi Academy did not, however, explicitly celebrate World Adivasi Day. According to Naranbhai Rathva, director of the Museum of Voice there, members of the Academy observed the day individually. He was in Bodeli, while his colleague Vikeshbhai spoke on Rathva culture at the Don Bosco school in Kavant, which remained in session.

41 Silver Spoon is the name of the restaurant from which the rally set off, but the billboard was actually set up on Station Road, about $1.4 \mathrm{~km}$ into the rally route. Vanar and Dadigam are villages in a part of Chhotaudepur sub-district that has extensive dolomite mines.

42 There was recognition that 2019 was to be the year of indigenous languages. This theme has local resonances. The museum of the Adivasi Academy is called The Museum of Voice (cf. Tilche 2011), its grounds contain a Bhasha Van, that is, a 'Language Grove', and the Bhasha Research and Publication Center, Vadodara, of which the Adivasi Academy is a unit, has coordinated the publication of the massive, 50-volume People's Linguistic Survey of India (Devy 2014). 
43 This is somewhat in the spirit of the ontological or, perhaps better, the recursive turn in anthropology - "to keep open [sic] the question of what phenomena might comprise a given ethnographic field and how anthropological concepts have to be modulated or transformed the better analytically to articulate them" (Holbraad and Pedersen 2017: 11; cf. Holbraad 2013) - although I doubt that it is ever wise or even possible to surrender the writer's second-order terms completely.

44 Information for Sápmi kindly provided by Siv Ellen Kraft and for Costa Rica by Bjørn Ola Tafjord.

45 www.facebook.com/aili.keskitalo.3/posts/10155417507122553

46 www.facebook.com/events/190519488335482/

47 https://presidencia.go.cr/temas/dia-internacional-de-los-pueblos-indigenas/ https:// presidencia.go.cr/comunicados/2018/08/gobierno-inicia-proceso-para-construirpolitica-publica-para-pueblos-indigenas/

48 https://surcosdigital.com/comunicado-de-frenapi-en-el-dia-internacional-de-lospueblos-indigenas/

49 Cf. Curl 2017; http://ipdpowwow.org/. According to one list, in 2017 four U.S. states, 58 U.S. cities, and three U.S. universities recognised the second Monday in October as Indigenous Peoples' Day (http://time.com/4968067/indigenous-peoplesday-columbus-day-cities/). In 2018 the number was higher - six states and more than 100 cities (www.smithsonianmag.com/blogs/national-museum-american-indian/2018/ 10/08/indigenous-peoples-day-2018/) - and one can only expect that number to grow. In Canada this Monday is celebrated as Thanksgiving Day; the Canadian National Indigenous Peoples' Day is 21st June, which, by declaration of the United Nations General Assembly, is the International Day of Yoga, celebrated in India and presumably elsewhere as such. In Australia First Nations people prefer to recognise 26th January as Invasion Day; cf. www.theguardian.com/commentisfree/2018/sep/25/you-can-haveaustralia-day-any-other-day-we-wont-accept-26-january-without-resistance.

$50 \mathrm{https} / /$ newsmaven.io/indiancountrytoday/news/it-s-a-good-day-to-be-indigenous-alist-of-indigenous-people-s-day-events-6q820YDFykOi9igt00JURQ/

51 https://indigenouswisdomsummit.com/library/8681

52 https://indigenouswisdomsummit.com/library/8681\#library

53 Cf. www.linkedin.com/in/mikuakrai, which lists an organisational connection to the International Commission for Dalit Rights. Rai does not, however, appear as a member of the board, staff, or advisory committee on the ICDR website.

54 www.facebook.com/shiftnetwork/videos/553583125080526/

55 Even www.hawaiinewsnow.com/story/15037594/abercrombie-signs-bill-recognizingnative-hawaiians/

56 Just how limited support is in this area was evident in the Lok Sabha (national parliament) elections in April and May 2019. The winner, Gitaben Rathva (BJP), received 651,093 votes $(61.92 \%)$. The runner-up, Ranjitsinh Rathava (Indian National Congress), received 333,339 votes (31.7\%). Rajesh Vasava, the candidate of the Bharatiya Tribal Party (which advocates for Bhilistan), received only 8400 votes, less than $1 \%$ of the total votes cast.

57 https://indianexpress.com/article/india/tribal-development-minister-ganpat-vasavachased-out-of-tribal-fair-in-narmada-police-launch-probe-5026125/

58 http://rathsena.abletribals.com/2018/06/12/objectives/

59 https://teersamachar.com/chhotaudepur-rathwa-jati-na-dakhla-mudde-tamam-paxno-bahishkar/

60 https://indianexpress.com/article/cities/ahmedabad/demand-for-tribal-status-rathwasto-boycott-political-activities-in-chhota-udepur-5516414/. The issue was relatively quiet in 2019 until 1st October, when four persons from Dahod district filed a public interest litigation petition with the High Court, asking the court to negate Rathva ST status. In response, a demonstration was held in Chhota Udepur to present a formal complaint to the district collector; news media reported that it was attended by 
more than 20,000 people. Subsequently, a complete, district-wide bandh was called for 14th and 15th November. See "Chhoțāudepur Jillo Tā. 14 ane 15 Navembere Sampūrṇ Bamdh Raheśe", Gujarat Samachar (Chhotaudepur edition), 11 October 2019.

61 As noted earlier, some attribute the general celebration of World Adivasi Day in Gujarat and other parts of India to the Indian government's refusal to acknowledge adivasis as indigenous when it ratified the U.N. Declaration on the Rights of Indigenous Peoples. Similarly, the proposal to re-classify Rathvas as non-tribal was first seriously floated in 2013 (Rathva, Rai and Rajaram 2014), and in the eyes of some participants, the agitation surrounding that proposal sparked greater interest in issues of Rathva identity and as a result in the Chhotaudepur celebration of World Adivasi Day.

62 https://teersamachar.com/chhotaudepur-adivasi-din-ni-ujavni/

63 e.g., many of the younger participants had to stand in line to have one or two older adivasis tie their turbans.

64 On 'indigenous religion(s)' see Tafjord (2013, 2017).

65 One option for doing so might have been to embrace notions of Hindutva as culture rather than religion, but this would be to surrender a distinctive adivasi-ness and to embrace of form of politics that many of the organisers reject.

\section{References}

Alles, Gregory D. 2013. "Do Ādivāsīs Have Religion? Contesting 'Religion' and 'Culture' in Eastern Gujarat". In Alternative Voices: A Plurality Approach for Religious Studies, edited by Afe Adogame, Magnus Echtler, and Oliver Freiberger. Göttingen: Vandenhoeck and Ruprecht, 21-35.

Arendt, Hannah. 1998 (1958). The Human Condition. 2nd edition. Chicago: University of Chicago Press.

Baird, Ian. 2018. "Considering the Implications of the Concept of Indigeneity for Land and Natural Resource Management in Cambodia, Thailand, and Laos". In Indigeneity on the Move: Varying Manifestations of a Contested Concept, edited by Eva Gerharz, Nasir Uddin, and Pradeep Chakkarath. New York: Berghahn Books, 49-68.

Baviskar, Amita. 2004. In the Belly of the River: Tribal Conflicts Over Development in the Narmada Valley. 2nd edition. New Delhi: Oxford University Press.

Butler, Judith. 2015. Notes toward a Performative Theory of Assembly. Cambridge, MA: Harvard University Press.

Cook, Joanna, James Laidlaw, and Jonathan Mair. 2009. "What if There Is No Elephant? Towards a Conception of an Un-Sited Field". In Multi-Sited Ethnography: Theory, Praxis and Locality in Contemporary Research, edited by Mark-Anthony Falzon. Farnham, Surrey: Ashgate, 47-72.

Curl, John. 2017. Indigenous Peoples Day: Handbook for Activists and Documentary History. Berkeley, CA: Indigenous Peoples Day Committee.

Davie, Grace. 1994. Religion in Britain since 1945: Believing Without Belonging. Oxford: John Wiley and Sons.

Devy, Ganesh N. (ed.). 2014. People's Linguistic Survey of India. New Delhi: Orient Blackswan.

Falzon, Mark-Anthony. 2009. "Multi-Sited Ethnography: Theory, Praxis and Locality in Contemporary Research". In Multi-Sited Ethnography: Theory, Praxis and Locality in Contemporary Research, edited by Mark-Anthony Falzon. Farnham, Surrey: Ashgate, $1-23$. 
Frost, Nicola. 2016. "Anthropology and Festivals: Festival Ecologies". Ethnos: Journal of Anthropology 81 (4): 569-583.

Gaier, Ulrich. 2009. "Myth, Mythology, New Mythology". In A Companion to the Works of Johann Gottfried Herder, edited by Hans Adler and Wulf Köpke. Rochester, NY: Camden House, 165-188.

Gerharz, Eva, Nasir Uddin, and Pradeep Chakkarath. 2018. Indigeneity on the Move: Varying Manifestations of a Contested Concept. New York: Berghahn Books.

Giddens, Anthony. 1990. The Consequences of Modernity. Cambridge: Polity Press.

Hannerz, Ulf. 1996. Transnational Connections: Culture, People, Places. London: Routledge.

Henry, Rosita. 2008. "Engaging with History by Performing Tradition: The Poetic Politics of Indigenous Australian Festivals". In The State and the Arts: Articulating Power and Subversion, edited by Judith Kapferer. New York: Berghahn Books, 52-69.

Hokowhitu, Brendan. 2014. "Haka: Colonized Physicality, Body-Logic, and Embodied Sovereignty". In Performing Indigeneity: Global Histories and Contemporary Experiences, edited by Laura R. Graham and H. Glenn Penny. Lincoln, NE: University of Nebraska Press, 273-304.

Holbraad, Martin. 2013. "A Comment on Franklin and Napier". Cambridge Anthropology 31: 123-127.

Holbraad, Martin and Morten Axel Pedersen. 2017. The Ontological Turn: An Anthropological Exposition. Cambridge: Cambridge University Press.

Johnson, Greg and Siv Ellen Kraft. 2018. "Standing Rock Religion(s): Ceremonies, Social Media, and Music Videos". Numen 65 (5-6): 499-530.

Longkumer, Arkotong. 2018. "Spirits in a Material World: Mediation and Revitalisation of Woodcarvings in a Naga Village". Numen 65 (5-6): 467-498.

Moodie, Megan. 2015. We Were Adivasis: Aspiration in an Indian Scheduled Tribe. Chicago: University of Chicago Press.

Mountford, Brian. 2011. Christian Atheist: Belonging without Believing. Winchester, UK: O-Books.

Mukherji, Partha Nath. 2009. "The Universal in the Particular: Universalising Social Science: Comparative Possibilities/Die Universele in die Besondere: Die universalisering van sosiale wetenskappe". Historia (South Africa) 54 (1): 129-146.

Mukherji, Partha Nath. 2013. "Conceptual-Theoretical Re-Orientation in Social Movement Discourse". Asian Journal of Social Science 41 (2): 105-125.

Munda, Ram Dayal. 2000. Adi-Dharam: Religious Beliefs of the Adivasis of India: An Outline of Religious Reconstruction with Special Reference to the Jharkhand Region. Coimbatore, India: Sarini.

Parmar, Ladhabhai Harji. 1903. The Rewakantha Directory. Rajkot: Damodar Goverdhandass Thakkar.

Phipps, Peter. 2016. "Indigenous Festivals in Australia: Performing the Postcolonial". Ethnos: Journal of Anthropology 81 (4): 683-696.

Rathva, Arjun, Dhananjay Rai, and N. Rajaram. 2014. "Denotification of the Rathvas as Adivasis in Gujarat". Economic and Political Weekly 49 (6): 22-24.

Rathva, Kanu. 2017. "Chhotāudepuramāṃ Birsā Muṃḍānī Mūrti Mūkāī”. Ādilok 9 (4): 46.

Shaw, Jane. 2008. The Mystical Turn: Religious Experience in the Modern World: The TwentyThird Eric Symes Abbott Memorial Lecture. London: King's College.

Singh, Kumar. S. 1983. Birsa Munda and His Movement, 1874-1901: A Study of a Millenarian Movement in Chotanagpur. Calcutta: Oxford University Press.

Strathern, Marilyn. 2004. Partial Connections. Updated edition. Walnut Creek, CA: Altamira Press. 
Symons, Jessica. 2016. "Shaping the Flow: Ethnographic Analysis of a Manchester Parade Event". Ethnos: Journal of Anthropology 81 (4): 697-711.

Tafjord, Bjørn Ola. 2013. "Indigenous Religion(s) as an Analytical Category". Method and Theory in the Study of Religion 25 (3): 221-243.

Tafjord, Bjørn Ola. 2017. "Towards a Typology of Academic Uses of 'Indigenous Religion(s)', or Eight (or Nine) Language Games That Scholars Play with This Phrase". In Handbook of Indigenous Religion(s), edited by Greg Johnson and Siv Ellen Kraft. Leiden: Brill, 25-51.

Taylor, Charles. 2007. A Secular Age. Cambridge, MA: Harvard University Press, 2007.

Tengan, Ty P. Kāwika. 2014. "The Return of Kū?: Re-Membering Hawaiian Masculinity, Warriorhood, and Nation”. In Performing Indigeneity: Global Histories and Contemporary Experiences, edited by Laura R. Graham and H. Glenn Penny. Lincoln, NE: University of Nebraska Press, 206-246.

Tilche, Alice. 2011. In Search of an Adivasi Worldview: Identity, Development and the Adivasi Museum of Voice in Western India. Ph.D. dissertation. School of Oriental and African Studies, University of London.

Uddin, Nasir, Eva Gerharz, and Pradeep Chakkarath. 2018. "Exploring Indigeneity: Introductory Remarks on a Contested Concept". In Indigeneity on the Move: Varying Manifestations of a Contested Concept, edited by Eva Gerharz, Nasir Uddin, and Pradeep Chakkarath. New York: Berghahn Books, 1-25.

Vasava, Anand. 2018. "Viśva Ādivāsī Din nimitte Guj. Yuni.māṃ yojāyo rāṣtrīyaa parisaṃvād". Ādilok 10 (5): 36-37.

Vasava, Shantikar. 2018. "Saṃyukt Rāṣṭrasaṃghan̄̄ sabhāmāṃ ādivāsī pratinidhitvā". Ádilok 10 (4): 32-33.

Venuti, Lawrence. 2013. Translation Changes Everything: Theory and Practice. London: Routledge.

Venuti, Lawrence (ed.). 2012. The Translation Studies Reader. 3rd edition. London: Routledge. Wagner, Peter. 2012. Modernity: Understanding the Present. Cambridge, UK: Polity Press. 